\title{
Wprowadzenie \\ Finansowanie szkolnictwa wyższego w warunkach permanentnej (międzysektorowej) konkurencji o środki publiczne
}

W bardzo ogólnym ujęciu publiczne wydatki na wszystkie usługi finansowane ze środków publicznych warto badać w kontekście gry o sumie zerowej: wyższe wydatki w jednym sektorze występują zawsze kosztem wydatków w innych sektorach usług publicznych. W Europie rośnie konkurencja o środki publiczne między szkolnictwem wyższym (wraz z akademickimi badaniami naukowymi), systemem emerytalnym i systemem ochrony zdrowia. Rośnie również niestabilność sektora publicznego połączona ze zmieniającymi się warunkami dostępu do finansowania. Reformy europejskich państw dobrobytu to przede wszystkim reformy tych trzech obszarów, które w największym stopniu pochłaniają dziś budżet przeznaczany na usługi publiczne (Leibfried i Mau 2008; Häusermann 2010; Pierson 2001).

Sektor szkolnictwa wyższego - aby wygrywać w tak rozumianej konkurencji z innymi częściami programów społecznych i programów państwa dobrobytu musi mieć $\mathrm{w}$ przyszłości bardziej przekonującą argumentację: po raz pierwszy w swojej powojennej historii będzie musiał starać się pokazywać bardziej szczegółowo wnoszone przez siebie korzyści dla społeczeństw i gospodarki, a nie tylko dla jednostek. To perspektywa zupełnie dla uczelni nowa - pokazująca zarazem, że muszą one przestać być traktowane (a zarazem przestać siebie traktować) jako instytucje, a zacząć być traktowane (i zacząć siebie traktować) jako organizacje.

W „złotej epoce” państwa dobrobytu nieustannie rosły nakłady na szkolnictwo wyższe i na akademickie badania naukowe (zwłaszcza na badania podstawowe w naukach ścisłych) (Ziman 1994); jednak umasowienie szkolnictwa wyższego zostało już osiągnięte w całej Europie, staliśmy się high participation systems. Dalszy rozwój sektora staje się zatem bardziej warunkowy - zostaje obwarowany nowymi wymaganiami i obarczany nowymi obowiązkami. Coraz silniejsze zmaga- 
nia o publiczne uznanie (a tym samym publiczne finansowanie) toczą się obecnie między wszystkimi usługami publicznymi. $Z$ darwinistycznej perspektywy ekologii organizacji (Hannan i Freeman 1989; Hannan, Pólos i Carroll 2007; Aldrich 2008) wszystkie sektory walczą o przetrwanie i wszystkie muszą się do nowej sytuacji stopniowo dostosowywać. Organizacje niedostosowane stracą najpierw społeczny szacunek, potem społeczne wsparcie, a na koniec - publiczne środki.

Można się spodziewać, że transformacje w sektorze usług publicznych będą przeprowadzane stopniowe i długofalowo (a nie gwałtownie i w krótkim czasie). Tworzenie architektury szkolnictwa wyższego $\mathrm{w}$ zakresie ustroju, zarządzania i finansowania w powojennej Europie zajęło kilka dekad; ich transformacja również zajmie kilka dziesięcioleci, a trwa przecież w Europie od co najmniej 20 lat. W przyszłości może się zwiększyć rola akumulacji drobnych, stopniowych, tym niemniej istotnych zmian (Mahoney i Thelen 2010; Streeck i Thelen 2005) (warto w tym kontekście wspomnieć o pozornie małej zmianie sposobu podziału dotacji podstawowej, która może istotnie zmienić funkcjonowanie uczelni, w tym nabory na studia, a nie jest nawet elementem zmian w ustawie o szkolnictwie wyższym).

Pomiary i rankingi konkurencyjności gospodarczej w coraz większym stopniu oznaczają pomiary i rankingi zarówno potencjału, jak i efektów funkcjonowania krajowych systemów szkolnictwa wyższego, akademickiej nauki i innowacji. Można się spodziewać, że szkolnictwo wyższe znajdzie się pod większym nadzorem, zarówno krajowym, jak i międzynarodowym (steering at a distance). Tradycyjne, a wypracowane po drugiej wojnie światowej, uzasadnienie dla przeznaczania potężnych publicznych środków finansowych na uniwersytety (prowadzące do bezwarunkowych i opartych na dwustronnym zaufaniu relacji państwo-akademia) zamienia się stopniowo w Europie w „podejście konkurencyjne” (Geuna 2001). Szkolnictwo wyższe i nauka akademicka zostają coraz szerzej wystawiane na oddziaływanie zasad quasi-rynkowych: współzawodniczą z potężnymi konkurentami zewnętrznymi (czyli zewnątrzsektorowo), a zarazem państwa coraz silniej stymulują konkurencję wewnętrzsektorową, czyli między instytucjami, grupami badawczymi i poszczególnymi naukowcami. Z idei permanentnej konkurencji na poziomie indywidualnym zrodziła się zarówno Europejska Rada ds. Badań Naukowych (ERC), jak i Narodowe Centrum Nauki (NCN). Z kolei z idei konkurencji na poziomie wydziałowym zrodził się Komitet Ewaluacji Jednostek Naukowych (KEJN) i jego ocena parametryczna. Tym samym system dotacji na badania i system grantów oparto - jak w całej Europie - na zasadach konkurencji.

We wszystkich europejskich systemach szkolnictwa wyższego i badań naukowych obserwujemy dziś koncentrację finansowania na badania w mniejszej niż dotychczas liczbie czołowych instytucji: coraz wyraźniej widzimy wygranych i przegranych nowych, bardziej konkurencyjnych praktyk alokacji środków finansowych, zgodnie z opisanym przez Roberta K. Mertona „efektem świętego Mateusza” w nauce, który odnosił się przede wszystkim do pojedynczych naukowców 
(„bogaci stają się coraz bogatsi w tempie, które sprawia, że biedniejsi stają się jeszcze bardziej biedni”; Merton 1973: 457), ale także do poziomu instytucjonalnego. Najlepszym przykładem mechanizmu kumulacji środków jest dzisiaj rozkład grantów z ERC nie tyle według krajów, ile według instytucji: połowa grantów idzie do 50 uczelni (na około 3300 w UE)), a w Polsce niemal wszystkie otrzymuje Uniwersytet Warszawski.

O podziale publicznych środków finansowych - w sytuacji zmniejszającej się podstawy podatkowej i rosnących wydatków innych niż edukacyjne w starzejących się społeczeństwach europejskich - coraz silniej decydować będzie nastawienie społeczeństw europejskich. Procesy te analizowałem jako zmieniające się społeczne „postawy wobec państwa dobrobytu”, którym będą towarzyszyć zmieniające się społeczne „postawy wobec uniwersytetów” (Kwiek 2015a). Tradycyjne postawy (a co za tym idzie - tradycyjne wzorce podziału środków publicznych) wcale nie muszą być w zmienionym kontekście demograficznym coraz starszej Europy tak życzliwe dla uczelni jak obecnie.

Dlatego podstawowym warunkiem utrzymania wysokiego wsparcia finansowego dla szkolnictwa wyższego jest silne wsparcie społeczne; to z niego może, choć nie musi, brać się wsparcie polityków. Priorytety publiczne zmieniają się na całym świecie, w różnym tempie w różnych jego częściach. Dla uniwersytetów europejskich liczy się przede wszystkim proces starzenia się Europy, ponieważ za dwie czy trzy dekady większość elektoratu będzie albo w zaawansowanym wieku produkcyjnym, albo już w wieku poprodukcyjnym. Równie ważne są zmiany demograficzne w Polsce.

Priorytety starszych pokoleń Europejczyków funkcjonujących w wyłaniających się nowych, prawdopodobnie coraz bardziej skomercjalizowanych systemach emerytalnych oraz w coraz bardziej sprywatyzowanej ochronie zdrowia mogą wyglądać odmiennie od priorytetów historycznie przyjmowanych w ostatnim półwieczu (Palier 2010; Powell i Hendricks 2009; Rothgang i in. 2010). Starzejące się społeczeństwa nie muszą automatycznie umieszczać wysoko instytucji szkolnictwa wyższego na swoich listach priorytetów finansowanych ze środków publicznych - o ile instytucje te same nie będą o to konsekwentnie i systematycznie zabiegać. W ramach dominującej przez ostatnie półwiecze logiki publicznego finansowania w Europie uniwersytetom należało się duże (i ciągle rosnące) finansowanie publiczne, a stojące za taką alokacją środków argumenty nie musiały być jakoś szczególnie eksponowane - ponieważ były uważane za oczywiste. I to się dziś zmienia. I nie mówimy o nakładach, które wciąż są bardzo wysokie i najczęściej rosnące; mówimy o dyskusjach o przyszłości, które toczą się najczęściej na poziomie ponadnarodowym, od OECD i Banku Światowego przez UNESCO po Komisję Europejską (Antonowicz 2015; Kwiek 2013). Jeśli chcemy poznać najbardziej prawdopodobne scenariusze przyszłości dotyczące finansowania uczelni, to czytajmy powstające tam dokumenty programowe. 
W ramach nowej logiki, według której rośnie rola konkurencji międzysektorowej, argumenty na rzecz silnego publicznego wsparcia uczelni muszą być prezentowane poniekąd od nowa, w znacząco mocniejszej, radykalnie bardziej przekonującej wersji. Dawne uzasadnienia już nie wystarczają, trzeba szukać nowych. W przeciwnym razie - jak pokazują najnowsze badania pauperyzacji kadry akademickiej w Europie i w świecie (Yudkevich, Altbach i Rumbley 2015; Altbach, Reisberg, Yudkevich, Androushchak i Pacheco 2012; Enders 2001) - dostęp młodych talentów do niedofinansowanych uczelni będzie coraz mniej prawdopodobny (Kwiek 2015b), a same uczelnie w związku z tym będą cieszyć się coraz mniejszym społecznym szacunkiem. Społeczeństwa przez swoich przedstawicieli - polityków - wyznaczają finansowe ramy swoim instytucjom; jeśli uznają, że długoterminowe inwestycje w wybrany sektor tracą na wartości, siłą rzeczy maleć będą publiczne nakłady. W jeszcze większym stopniu niż uczelni procesy te dotyczą akademickich badań naukowych.

Można się też obawiać negatywnego sprzężenia zwrotnego - mniejsze nakłady mogą powodować odwrót najlepszych młodych umysłów od uniwersytetów, co zmniejsza społeczne uznanie dla tej instytucji i jeszcze bardziej zmniejsza poziom jej gwarantowanego, publicznego finansowania (Kwiek 2015c). Procesy te mają naturę globalną, a najbardziej zaawansowane są w krajach anglosaskich. W tradycyjnym europejskim ujęciu instytucji uniwersytetu atrakcyjność akademickiej kariery zawodowej bezsprzecznie maleje - a konkurują z nią tym bardziej inne sektory gospodarki, im bardziej praca akademicka zaczyna przypominać pracę w korporacji (jednak o znacząco niższym wynagrodzeniu).

Szkolnictwo wyższe, pośród eskalacji kosztów wszystkich usług publicznych w dzisiejszym świecie, musi zatem w jasny sposób wykazywać niekwestionowaną dotąd (na taką skalę jak dzisiaj) wartość dostarczanych usług. Najważniejsza dla społeczeństwa staje się wartość wszystkiego tego, co tworzy szkolnictwo wyższe, która jest jednak zawsze relatywna wobec wartości rezultatów społecznych możliwych do osiągnięcia przy wykorzystaniu tych samych publicznych środków finansowych gdzie indziej (Salerno 2007): emerytury, ochrona zdrowia, pomoc społeczna, obronność, porządek publiczny, infrastruktura, szkolnictwo podstawowe i średnie itd.

W coraz większym stopniu przyszłość uczelni będzie zatem ujmowana w kategoriach finansowych, co wydawało się jeszcze niedawno nie do pomyślenia (Teixeira 2009; Szadkowski 2015). Stosowanie kategorii finansowych do funkcjonowania uczelni budzi zrozumiały opór w całej Europie, jednakże szkolnictwo wyższe to setki miliardów euro inwestycji i 20 milionów studentów; to również nieznane wcześniej oczekiwania społeczne i gospodarcze wobec uczelni, dotyczące szczególnie ich bliższych związków z gospodarką oraz z potrzebami społecznymi. Academic excellence i economic relevance to trudne do pogodzenia ideały. 
Stopniowe przechodzenie od logiki akademickiej (dominującej w małych, elitarnych systemach) do logiki finansowej (dominującej w systemach masowych) w myśleniu o funkcjonowaniu szkolnictwa wyższego to jedno z największych wyzwań, z którymi musi się dziś zmierzyć kadra akademicka w Europie. Część zachodzących zmian dobrze tłumaczy analizowana tu skrótowo rosnąca konkurencja międzysektorowa o środki publiczne. Na dłuższą metę abstrahowanie od tak rozumianej konkurencji w rozważaniach o przyszłości europejskich uczelni może okazać się kontrproduktywne - będziemy bowiem coraz gorzej rozumieli podstawowe reguły ich funkcjonowania. A tym samym stopniowo będzie malał nasz realny wpływ na ich przyszłość.

prof. dr hab. Marek Kwiek

\section{Podziękowania}

Wydanie tego numeru nie udałoby się bez wsparcia udzielonego przez Narodowe Centrum Nauki (NCN) w ramach projektu MAESTRO (Program Międzynarodowych Badań Porównawczych Szkolnictwa Wyższego DEC-2011/o2/A/HS6/o0183) oraz przez Fundację na Rzecz Nauki Polskiej (FNP) w ramach projektu MISTRZ (subsydium profesorskie - umowa 5/2015). Wyrażam niniejszym swoją głęboką wdzięczność obydwu instytucjom.

\section{Literatura}

Aldrich, H.E. (2008). Organizations and Environments. Stanford: Stanford University Press.

Altbach, Ph.G., Reisberg, L., Yudkevich, M., Androushchak, G., Pacheco, I. (red.) (2012). Paying the Professoriate. A Global Comparison of Compensation and Contracts. New York: Routledge.

Antonowicz, D. (2015). Między siłą globalnych procesów a lokalną tradycją. Polskie szkolnictwo wyższe $w$ dobie przemian. Torun: Wyd. Naukowe UMK.

Enders, J. (red.) (2001). Academic Staff in Europe. Changing Contexts and Conditions. Westport - London: Greenwood Press.

Geuna, A. (2001). The Changing Rationale for European University Research Funding: Are There Negative Unintended Consequences? Journal of Economic Issues. Vol. XXXV, 3: 607-632.

Hannan, M.T., Freeman, J. (1989). Organizational Ecology. Cambridge, MA: Harvard University Press.

Hannan, M.T., Pólos, L., Carroll, G. R. (2007). Logics of Organization Theory. Audiences, Codes, and Ecologies. Princeton: Princeton University Press.

Häusermann, S. (2010). The Politics of Welfare State Reform in Continental Europe: Modernization in Hard Times. Cambridge: Cambridge University Press.

Kwiek, M. (2013). Knowledge Production in European Universities. States, Markets, and Academic Entrepreneurialism. Frankfurt - New York: Peter Lang.

Kwiek, M. (2015a). Uniwersytet $w$ dobie przemian. Instytucje $i$ kadra akademicka $w$ warunkach rosnacej konkurencji, Warszawa: Wyd. Naukowe PWN. 
Kwiek, M. (2015b). Młoda kadra: różnice międzypokoleniowe w pracy naukowej i produktywności badawczej. Czym Polska różni się od Europy Zachodniej? Nauka. 3: 51-88.

Kwiek, M. (2015c). Reformy uniwersytetów europejskich: państwo dobrobytu jako brakujący kontekst badań i polityki publicznej. Człowiek i Społeczeństwo. 39: 165-196.

Leibfried, S., Mau, S. (red.) (2008). Welfare States: Construction, Deconstruction, Reconstruction. Cheltenham: Edward Elgar.

Mahoney, J., Thelen, K. (red.) (2010). Explaining Institutional Change. Ambiguity, Agency, and Power. Cambridge: Cambridge University Press.

Merton, R.K. (1973). The Sociology of Science: Theoretical and Empirical Investigations. Chicago: University of Chicago Press.

Palier, B. (red.) (2010). A Long Goodbye to Bismarck? The Politics of Welfare Reform in Continental Europe. Amsterdam: Amsterdam University Press.

Pierson, P. (2001). Coping with Permanent Austerity: Welfare State Restructuring in Affluent Democracies. W: Pierson (red.), The New Politics of the Welfare State (369-406). Oxford: Oxford University Press.

Powell, J., Hendricks, J. (red.) (2009). The Welfare State in Post-Industrial Society. A Global Perspective. Dordrecht: Springer.

Rothgang, H., Cacace, M., Frisina, L., Grimmeisen, S., Schmid, A., Wendt, C. (2010). The State and Healthcare: Comparing OECD Countries. Basingstoke: Palgrave Macmillan.

Salerno, C. (2007). A Service Enterprise: The Market Vision. W: P. Maassen, J.P. Olsen (red.), University Dynamics and European Integration (119-132). Dordrecht: Springer.

Streeck, W., Thelen, K. (red.) (2005). Beyond Continuity. Institutional Change in Advanced Political Economies. Oxford: Oxford University Press.

Szadkowski, K. (2015). Uniwersytet jako dobro wspólne. Podstawy krytycznych badań nad szkolnictwem wyższym. Warszawa: Wyd. Naukowe PWN.

Teixeira, P. (2009). Economic Imperialism and the Ivory Tower: Some reflections Upon the Funding of Higher Education in the EHEA (2010-2020). W: B.M. Kehm, J. Huisman, B. Stensaker (red.). The European Higher Education Area: Perspectives on a Moving Target (43-60). Rotterdam - Boston - Taipei: Sense Publishers.

Yudkevich, M., Altbach, Ph.G., Rumbley, L.E. (red.) (2015). Young Faculty in the Twenty-First Century. International Perspectives. Albany: SUNY Press.

Ziman, J. (1994). Prometheus Bound. Science in a dynamic steady-state. Cambridge: Cambri-dge University Press.

CYTOWANIE: Kwiek, M. (2016). Wprowadzenie. Finansowanie szkolnictwa wyższego w warunkach permanentnej (międzysektorowej) konkurencji o środki publiczne. Nauka i Szkolnictwo Wyższe. 1(47): 7-12. DOI: 10.14746/nisw.2016.1.o. 